\title{
从哺乳动物化石来探讨北京猿人 生活环境的变迁
}

\author{
李炎贤计后样 \\ (中国科学院古准动物与古人类研究所)
}

关于北京猿人生活时期周口店附近的自然环境, 中外学者叠有讨论, 但诸说不一[1-6]. 本 文作者主要从哺乳动物化石的角度来探讨这个问题.

北京猿人遗址发现的哺乳动物化石, 从动物地理学的观点看来, 可以分为三类: (1)广泛 分布于古北界和东洋界的种类; (2)限于古北界的种类; (3)属于东洋界的成份,如水牛、象等. 由于大部份哺乳动物化石是温带古北界的种类，其中多数和今天华北地区的现生种类相同或 相近,似乎表示北京猿人生活时期的自然环境和现今华北地区者相似, 属于温带气候. 东洋界 的成份中, 有些种类现在的分布只限于淮河以南地区,有些则更为向南或更远, 这似乎表示北 京猿人生活时期周口店附近的气候比今日为温暖潮湿. 古北界的种类中有几个种类现在分布 在比周口店附近较为寒冷的地区,似乎表示北京猿人遗址堆积期间气候有过波动,有时可能比 较干燥凉爽. 但问题在于这些“喜冷”的动物往往和“喜暖”的动物发现于同一层位. 是否这些 “喜冷”的动物在北京猿人生活时期还是适应于温暖气候, 只是到了后来才变为适应较为寒冷 的气候,这是需要进一步考虑的. 总的说来,除了适应性较广的种类外，“喜暖”的种类多于“喜 冷”的种类,北京猿人遗址发现的动物群所表示的气候环境，似应为间冰期情况，而不是冰期的 情况.

从动物群的生态分析,大致可分为下列几类: (1)适应生态环境幅度较大的种类,如狼、赤 狐等. (2) 习惯栖息于森林的种类,如狝猴、象，大部份食肉类,啮齿类中的河狸、豪猪、小林姬 鼠、棕背慨; 偶蹄类中的水牛、野猪、斑鹿、䧹等.（3）习惯栖息于草原或千燥地区的种类，如肉

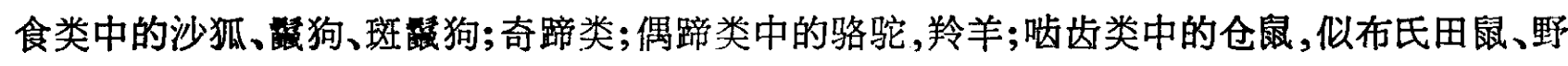
原鼠、简田鼠及旱獭等. 另外还有驼鸟. (4)习惯栖息山地的种类,如柯氏鼠兔、山鼠及大熊猫 等.（5）习惯于栖息丛林或疏林草原的种类, 如河狸、水獭、水牛、步氏水狍、中国水䢻、中国貉 及黑鼠等.

这几种生活习性不同的动物, 发现于同一层位之中, 表示周口店附近不是单一的自然景 观, 而是有山地、平原、河湖沼泽,山上有森林, 平原上是草原, 甚至存在较千旱的草地. 北京猿 人生存时的地貌同现在相似,其自然景观是在高山上有茂密的森林, 平原上是草地, 河湖沼泽 星罗棋布.

北京猿人遗址堆积厚达 40 余米, 分为 13 层, 代表相当长的时期, 从堆积物的岩性分析, 狍 粉及动物群的分析, 显示出气候有波动, 但各学科的着眼点不同, 得出结论不完全一致, 是可以 
理解的.

第 13 层发现化石少: 有扁角鹿、中国裂狗、三门马及大丁氏等, 似乎代表草原一河沼 生活种类的存在. 第 12 层有周口店双角犀,也是草原生活的种类. 第 11 层共 29 个种类,草原 与林栖动物的比例是 55\%:45\% 。第 10 层共发现 28 个种类, 草原与森林动物的比例 接近. 第 8一- 层共 38 个种类,森林动物占优势,肉食类发现多,啮齿类少,草原啮齿类未见; 说明这 时的气候是温暖湿润. 第 7 层发现有 17 个种类，林栖动物多于草原动物，最突出之点为喜水 或近水种类占相当比例,可以推测当时为多水潮湿时期. 第 6 层有 18 个种类,情况似 7 层.第 5 层有 29 个种类,林栖动物比例高, 肉食类占一半以上, 有喜水或近水的种类,联系到岩性为 钟乳石层,当时的气候是温湿. 第 4 层发现的哺乳动物有 20 个种类,肉食类减少,啮齿类比例 最高,草原动物的比例增加并超过森林动物,说明当时的气候有变化,森林面积缩小,草原面积 扩大. 第 1-3 层的动物化石显示出以草原为主的草原一森林景观.

如上所述,北京猿人生活时期的自然环境变化情况,可大致推测如下:

第 13-12 层由于材料少，难于推测过多．从第 11 层起，大致可以分为三个段落.（1） 11-10 层:草原动物多于森林动物.（2）9-5 层:森林动物多于草原动物,喜水或潮湿动物多 于习惯栖息于较干燥地区的动物. 其中 9-8 层森林动物最多,偏南种类多；7 层喜水种类多， 没有特别喜干爆种类；6层与 5 层森林动物多于草原动物，仍有喜水或近水种类.（3）4-1 层: 森林动物减少,草原动物相对增加. 第 4 层中喜水与喜千檈种类的比例差不多,地理分布 偏南的种类多于偏北的种类; 第 3-1 层中喜欢干燥环境的种类多于喜欢潮湿的种类，偏南的 种类较多. 因此, 可以进一步地推论, 第 10-11 层可能为温带气候, 第 5-9 层为温暖湿润的 气候, $1-4$ 层又转为温带半干旱气候.

综上所述,我们认为北京猿人生存时的气候是温带气候, 和今日华北气候接近, 但比今日 稍暖和湿润。其间气候呈多次波动，特别是在中间一个阶段较为温湿。

\section{考文献}

[1] 柯登,古脊椎动物与古人类, 2 (1960), 2: 167-168.

[2]周本婎,古脊推动物与古人类, 16 (1978), 1: 47-59.

[3] 周明镇, 中国人类化石的发现与研究, 1955, 19-38.

[4] 裴文中, 古辁倠动物与古人类, 2(1960), 1: 9-21.

[.5]贯兰坡,地层学杂志, 2 (1978), 1: 53-56.

[6] 徐仁, 中国第四纪研究, 4 (1965), 1: 77-83. 